\title{
Respiratory cancer and air pollution from iron foundries in a Scottish town: an epidemiological and environmental study
}

\author{
G H SMITH, F L R WILLIAMS, O L L LLOYD
}

From the Environmental Epidemiology and Cancer Centre, Department of Community Medicine, Ninewells Medical School, Dundee DDI 9SY, UK

\begin{abstract}
A geographical association between respiratory cancer and air pollution from steel foundries has been shown previously in Scotland and elsewhere. In the present study the ironfounding town of Kirkintilloch was found to have standardised mortality ratios (SMRs) for respiratory cancer in 1959-63, 1964-8, and 1969-73 that were unexceptional in comparison with Scotland. Nevertheless, when SMRs were calculated for respiratory cancer for the period 1966-76 in five zones of the town arranged, a priori, according to probable exposure to fumes from two iron foundries, and in the individual enumeration districts of the 1971 census, higher SMRs were found in the residential areas most exposed to pollution from the foundries. The gradient of the zones' SMRs - high close to the foundries to low at some distance from them-persisted despite standardisation of the SMRs for social class. A survey of the concentrations of several metals in soil cores sampled at 51 sites throughout the town showed a pattern of pollution that probably illustrated the effects of prevailing winds and topography on the pollution plumes from the foundries. The value of sampling soil cores in investigations where historical sources of metallic air pollution are of epidemiological interest was emphasised by the detection of high concentrations of $\mathrm{Ni}$ in an area where a nickel refinery had been located many decades previously.
\end{abstract}

Epidemiological studies have indicated that foundry workers are more likely to contract respiratory cancer than are other occupational groups, perhaps as a result of exposure to "hot metal" fumes. ${ }^{1-4}$ The possibility, however, of carcinogenic effects resulting from environmental exposure to metallic air pollutants emitted from foundries has not been studied to the same extent. Although such exposures are at far lower concentrations than those encountered in the workplace, they may take place over much longer periods.

In two towns in central Scotland a geographical association has been shown between pollution from steel foundries and mortality from respiratory cancer. ${ }^{5-8}$ The pattern of pollution flow from the steel foundries was estimated from the patterns of the metal concentrations measured in various low technology samplers including moss, ${ }^{910}$ lichens, ${ }^{11} 12$ and soils, ${ }^{13-15}$ and also through the use of models of the towns in a wind tunnel. ${ }^{6}{ }^{16}$ In the present study we

Accepted 10 November 1986 examined the distributions of respiratory cancer and of metallic pollution of the soil within a town containing an iron foundry industry.

Kirkintilloch is an industrial town in west central Scotland with a population of about 33000 . The town, which dates back to $200 \mathrm{AD}$, has a varied industry, but since the early nineteenth century the main heavy industry has been iron production. ${ }^{17}$ Several foundries were established and for many years the industry flourished because the Forth and Clyde Canal, which runs through the town, allowed the bulk ore to be transported cheaply. In recent times a declining demand for iron caused a fall in output and during the past decade only two foundries have remained active. At the time of the environmental study (1983) only one of these foundries, termed "the active foundry" in the text, continued in production. This foundry was in the valley beside the Forth and Clyde Canal in the north of the town. The other foundry, which closed in 1981, was on a higher site near the centre of the town.

In the present study we tested the hypothesis that 
residential areas exposed to air pollution from iron foundries showed a higher mortality from respiratory cancer than areas with less or no exposure. The study had four components. Firstly, the mortality for respiratory cancer for the whole town was compared with the Scottish experience during three five year periods between 1959 and 1973. Secondly, the geographical distribution of respiratory cancer was determined by residence within various subdivisions of the town during 1966-76; this period contained the census year of 1971 as its demographic centre point, and the years on either side contributed adequate numbers of deaths in the small areas for statistical analyses. ${ }^{5-8}$ Thirdly, the pattern of soil contamination by various metals was investigated. Finally, the association between the epidemiological and pollution patterns within the town was investigated in relation to the location of the iron foundries.

\section{Methods}

To calculate the standardised mortality ratios (SMRs) for primary respiratory cancer in Kirkintilloch during 1959-63, 1964-8, and 1969-73, the observed numbers of deaths in the town during those years were obtained from the annual reports of the Registrar General for Scotland. The expected numbers of deaths were calculated by indirect standardisation, using the census populations of the town in 1961 and 1971 and the Scottish rates for those census years; the 1966 population was derived by interpolation between the 1961 and 1971 censuses.

The addresses of residents of Kirkintilloch who had died from primary respiratory cancer (ICD 8:162) between 1966 and 1976 were obtained from the mortality registers of the town and were plotted on a map. The numbers of deaths for the individual enumeration districts of the 1971 census within the main area of Kirkintilloch were counted. The expected numbers of deaths in those districts were calculated by indirect standardisation using the Scottish rates for respiratory cancer in 1971. The SMRs were calculated for men and women combined.

The enumeration districts were aggregated a priori into five zones (fig 1) of probable exposure to air pollution from the two foundries, taking into account the topography of the town, the prevailing wind directions, and the proximity of the enumeration districts to those foundries. The most "at risk" area encompassed zones $A$ and $B$, lying to the east and west respectively of the active foundry and also containing the closed foundry. The area at intermediate risk, zones $\mathrm{C}$ and $\mathrm{D}$, was near the closed foundry but not within the area probably exposed to air pollution carried by the prevailing winds. The low risk area, zone $\mathrm{E}$, was furthest from the foundries, in the south of the town. The SMRs of these five zones were derived $\overline{\bar{z}}$ from the aggregated expected and observed numbers $\bar{z}$ of deaths calculated for the individual enumeration $\underset{\propto}{\stackrel{\circ}{\circ}}$ districts. The mean age specific rates for men in the zones were also calculated (the female rates were not $\stackrel{\vec{\rho}}{?}$ calculated because of the problem of interpreting? small numbers). The statistical significance of the SMRs was assessed by calculating their $95 \% \frac{\bar{m}}{\frac{\bar{c}}{\sigma}}$ confidence limits ${ }^{18}$ in two stages: firstly, for the SMRs $\varnothing$ of the five zones and, secondly, for the SMRs of the individual enumeration districts. Those districts where the SMR was either over 150 or statistically $\vec{\circ}$ significantly high were noted on a map.

The social class distribution of the populations in $\stackrel{\vec{\omega}}{\circ}$ the town's zones was calculated according to the $\stackrel{\odot}{\bar{D}}$ occupation of the head of the household, the data 3 being derived from the 1971 census. The percentages of households for each category (social classes I, II, $\stackrel{\vec{N}}{\vec{n}}$ IIIn, IIIm, IV, and V) were calculated for each zone. ? (Data for the social class compositions at 1971 were $c$ of no longer available in the format of the 1971 enumer- 0 ation districts, and so were taken in the format of the enumeration districts of the 1981 census which were $\vec{\nabla}$ approximately coterminous.) The SMRs of the five $\mathbb{D}$ zones were standardised for social class.

To assess the homogeneity of the town's population, the percentages in each zone of the inhabitants born in Scotland, in the remainder of the United $\overrightarrow{0}$ Kingdom, in Eire, and elsewhere were obtained fro the census data for 1971. To observe any influence of occupation on zone of residence, the occupations the cases of respiratory cancer were ascertained, and the zones containing their residences were noted.

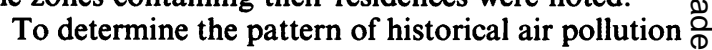
by metals, the contamination of soils in the major housing areas of the town was studied. Fifty one soil $\overrightarrow{\overrightarrow{0}}$ sites were chosen to cover the town. To observe more 3 closely the possible effects of topography on the channelling of pollution flow, the density of sites was increased in the vicinity of the canal that ran northeast from the active foundry, along the base of the $\frac{\mathbb{S}}{3}$ small hill there. The sampling sites were in areas of 0 grassland $^{15}$ that appeared to have been undisturbed or uncultivated for several years and were at least $4 \mathrm{~m} \delta$ from potential contamination sources such as roads $₹$ and wire fences. An auger was used to extract vertical $ᄋ$ soil cores of $2 \times 20 \mathrm{~cm}$, and the $\mathrm{pH}\left(\mathrm{H}_{2} \mathrm{O}\right)$ of the samples was measured at the time of sampling. To assess the reliability of the soil sampling technique as an indicator of atmospheric pollution, the soil cores were $\sigma$ separated into halves, and sealed in coded plastic bags $N$ to enable laboratory analysis to be performed $\underset{\mathrm{C}}{\mathrm{N}}$ "blind." The concentrations in the upper and lower halves of the soil cores were calculated for each site.

After being oven dried at $100^{\circ} \mathrm{C}$, the samples were $\frac{0}{\Phi}$ ground using a pestle and mortar, passed through a 


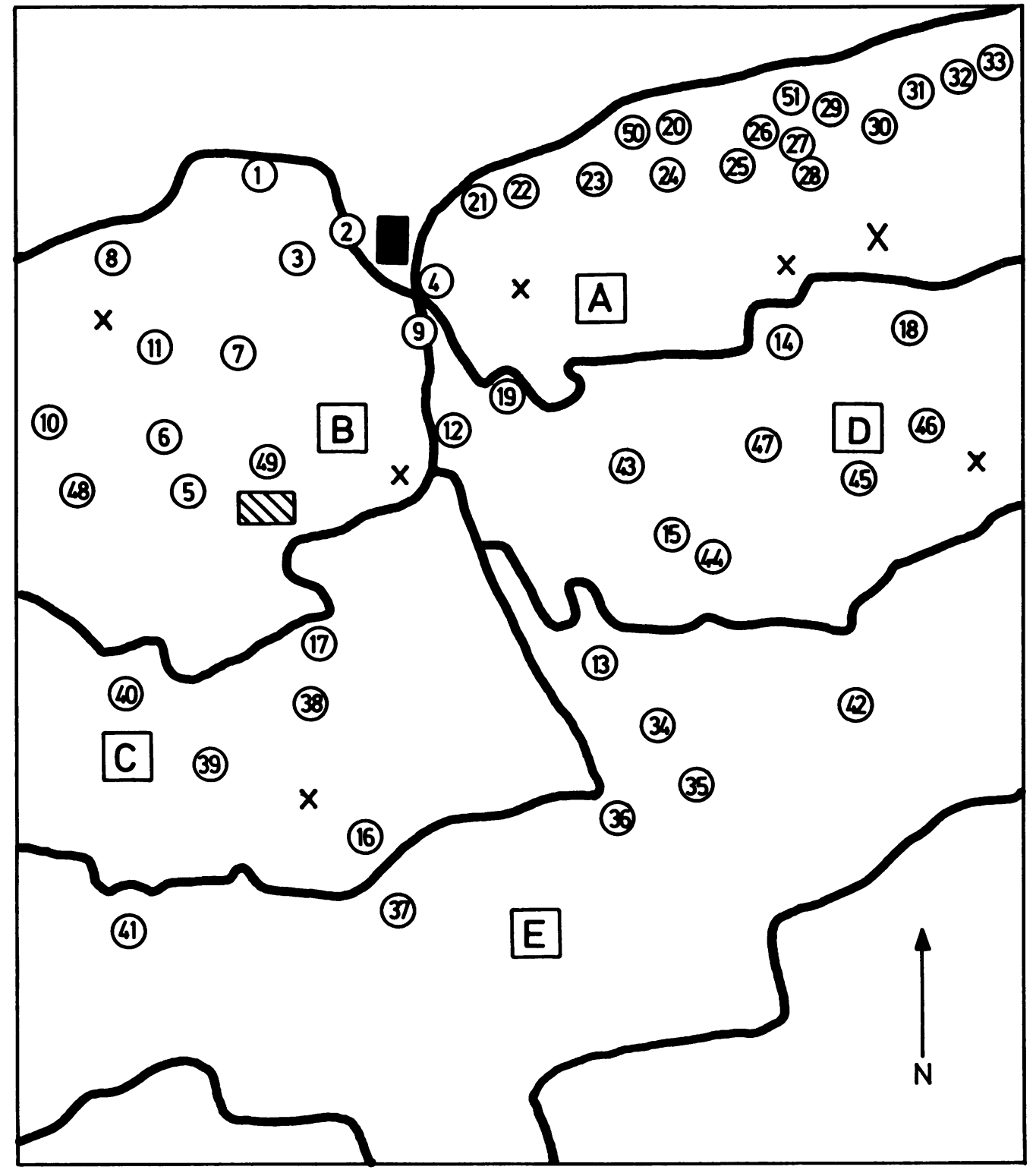

Active foundry

$\triangle$ Closed foundry

$X$ Enumeration district with significantly high SMR

$\times$ SMRs $>150$

Fig 1 Schematic map of Kirkintilloch showing the residential zones $A-E$, the positions of the two iron foundries, and the 51 sites used for soil sampling.

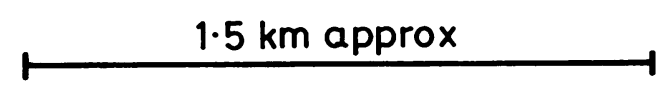


soil sieve (mesh size $2 \mathrm{~mm}$ ), and digested using a mixture of $50 \% \mathrm{HNO}_{3}$ and $\mathrm{H}_{2} \mathrm{O}_{2}$. All glassware and apparatus in contact with the soils had previously been acid washed to remove metal contaminants. The samples simmered on a hot plate for six hours and were then filtered and made up to a total volume of $50 \mathrm{ml}$ with distilled water. Flame atomic absorption spectrophotometry was used to determine the concentrations of iron $(\mathrm{Fe})$, manganese $(\mathrm{Mn})$, copper $(\mathrm{Cu})$, chromium $(\mathrm{Cr})$, lead $(\mathrm{Pb})$, and nickel $(\mathrm{Ni})$ at the individual sites. ${ }^{15}$

For each of the five zones, the mean values of their sites, with their standard deviations and ranges, were calculated. The individual sites were then ranked in order of concentration for each metal, firstly within each zone and, secondly, within the town as a whole. The sites of the top 10 and 20 values of each metal were plotted on maps. The correlations between the ranks of the metals at the sites were assessed using Spearman's rank correlation ${ }^{19} ; \mathrm{Pb}$ and $\mathrm{Ni}$ were excluded from the comparisons because they had sources other than the foundries.

Spearman's rank correlation was also used between the ranks of each zone's SMR and its mean content of each metal.

An attempt to use spherical moss bags to measure the current levels of metallic pollution within the town was discontinued owing to the repeated theft of samplers from some sites.

\section{Results}

For Kirkintilloch as a whole during recent decades, mortality from respiratory cancer was unexceptional compared with that of Scotland: for 1959-63, 1964-8, and 1969-73 the SMRs were 93.5 (37 deaths), 114.2 (60 deaths), and 90.6 (57 deaths) respectively.

Within the town, the highest SMRs were in zones $A, B$, and C; significantly low SMRs were found in zones $\mathrm{D}$ and $\mathrm{E}$ (table 1).
Zones A, B, and D were predominantly class IIIm, zone $C$ was predominantly classes II and IIIm, and zone E classes I and II. After standardising for social class, the SMRs of most zones decreased, particularly that of zone $\mathrm{A}$, but the gradient declining from zones $A, B$, and $C$ to zone $E$ remained.

The percentages of male inhabitants born in Scotland in zones A $(97 \%)$ and B $(91 \%)$ were similar to those in the remainder of the town $(92 \%)$. Of the eight deaths where the occupation on the death certificate was shown as iron foundry worker, one residence was in zone $\mathrm{A}$ (aged 71), five in zone $\mathrm{C}$ (aged 61, 64, 64, 75, 76 ), one in zone D (aged 68), and one in zone $E$ (aged 67).

The age specific rates for men in the age group 45-54 were higher in zones $A$ and $B$ than in the other zones or in Scotland. In the age group 55-64 zone C had the highest SMR but those of zones A and B were intermediate and lower than the Scottish value. Although the values in the older age groups did not 0 show consistent trends, the values in zone A exceeded those for Scotland.

In the individual enumeration districts, the only significantly raised SMR (369) was in zone A to the east of the active foundry and about $1.4 \mathrm{~km}$ from it (fig 1). Of the other six SMRs with values over 150, four were in the high risk zones (zones A and B) and two were in the intermediate risk zones (zones and D).

The mean values of most of the metals were highes in zones $\mathrm{A}$ and $\mathrm{B}$, intermediate in zones $\mathrm{C}$ and $\mathrm{D}$, an $\mathrm{A}$ lowest in zone $\mathrm{E}$ (table 2); $\mathrm{Ni}$ and $\mathrm{Pb}$ did not show a clear gradient, their values being higher in zone $\mathrm{C} \cong$ than in zone $\mathrm{A}$. In zone $\mathrm{A}$ the correlations between $\triangle$ the values of $\mathrm{Fe}$ and $\mathrm{Mn}$ and $\mathrm{Cu}$ and $\mathrm{Cr}$ at individual sites were all positive, and for $\mathrm{Mn}$ and $\mathrm{Cr}$ they were also highly significant (table 3 ); zone E contained the only correlation which was both negative and statistically significant-that between $\mathrm{Fe}$ and $\mathrm{Cu}$. Table 4 shows the correlations between the mean metal con-

Table 1 SMRs for lung cancer by zone in Kirkintilloch (1966-76). (Numbers of deaths in parentheses)

\begin{tabular}{|c|c|c|c|c|c|}
\hline \multirow[b]{2}{*}{$S M R s$} & \multicolumn{2}{|l|}{ High risk } & \multicolumn{2}{|c|}{ Intermediate risk } & \multirow{2}{*}{$\frac{\text { Low risk }}{\text { Zone } E}$} \\
\hline & Zone A & Zone B & Zone C & Zone $D$ & \\
\hline $\begin{array}{l}\text { Male } \\
\text { CI }\end{array}$ & $\begin{array}{r}111(20) \\
68-172\end{array}$ & $\begin{array}{r}100(21) \\
62-152\end{array}$ & $\begin{array}{r}102(19) \\
61-159\end{array}$ & $\begin{array}{l}62(16) \\
36-101\end{array}$ & $\begin{array}{l}34(5) \\
11-79\end{array}$ \\
\hline $\begin{array}{l}\text { Female } \\
\text { CI }\end{array}$ & $\begin{array}{l}225 \quad(9) \\
103-427\end{array}$ & $\begin{array}{r}110(6) \\
40-240\end{array}$ & $\begin{array}{r}113 \quad(5) \\
37-265\end{array}$ & $\begin{array}{r}101(6) \\
37-220\end{array}$ & $\begin{array}{l}56(2) \\
7-203\end{array}$ \\
\hline $\begin{array}{l}\text { Male and female } \\
\text { CI }\end{array}$ & $\begin{array}{r}132(29) \\
88-189\end{array}$ & $\begin{array}{r}102(27) \\
67-148\end{array}$ & $\begin{array}{r}104(24) \\
67-155\end{array}$ & $\begin{array}{l}70(22) \\
44-105\end{array}$ & $\begin{array}{l}38(7) \\
15-79\end{array}$ \\
\hline $\begin{array}{l}\text { Male and female } \\
\text { adjusted for SC } \\
\text { CI }\end{array}$ & $\begin{array}{l}116 \\
78-167\end{array}$ & $\begin{array}{l}101 \\
67-147\end{array}$ & $\begin{array}{l}101 \\
65-150\end{array}$ & $\begin{array}{l}63 \\
40-95\end{array}$ & $\begin{array}{l}45 \\
18-93\end{array}$ \\
\hline
\end{tabular}

CI, $95 \%$ Confidence interval. SC, Social class. 
Table 2 Concentrations (in $\mathrm{mg} / \mathrm{kg}$ ) of metals in soil samples from sites in five zones in Kirkintilloch: means, standard deviations $(S D)$, and ranges of values

\begin{tabular}{|c|c|c|c|c|c|c|}
\hline Zone & $\mathrm{Fe}$ & $M n$ & $C u$ & $C r$ & $\mathrm{Ni}$ & $P b$ \\
\hline $\begin{array}{l}\text { Zone A (17 sites): } \\
\text { Means } \\
\text { SD } \\
\text { Ranges }\end{array}$ & $\begin{array}{l}22635 \\
7052 \\
13700-32530\end{array}$ & $\begin{array}{l}579 \\
122 \\
380-890\end{array}$ & $\begin{array}{l}40 \\
12 \\
26-60\end{array}$ & $\begin{array}{l}52 \\
11 \\
38-71\end{array}$ & $\begin{array}{l}38 \\
14 \\
29-88\end{array}$ & $\begin{array}{l}128 \\
64 \\
69-331\end{array}$ \\
\hline $\begin{array}{l}\text { Zone B (12 sites): } \\
\text { Means } \\
\text { SD } \\
\text { Ranges }\end{array}$ & $\begin{array}{l}20949 \\
3044 \\
15460-26880\end{array}$ & $\begin{array}{l}573 \\
129 \\
370-740\end{array}$ & $\begin{array}{l}40 \\
33 \\
12-136\end{array}$ & $\begin{array}{l}53 \\
13 \\
29-73\end{array}$ & $\begin{array}{l}75 \\
91 \\
23-352\end{array}$ & $\begin{array}{l}254 \\
154 \\
70-509\end{array}$ \\
\hline $\begin{array}{l}\text { Zone C (5 sites): } \\
\text { Means } \\
\text { SD } \\
\text { Ranges }\end{array}$ & $\begin{array}{l}19195 \\
3628 \\
16710-25475\end{array}$ & $\begin{array}{l}392 \\
68 \\
290-460\end{array}$ & $\begin{array}{l}37 \\
10 \\
26-50\end{array}$ & $\begin{array}{l}40 \\
4 \\
36-46\end{array}$ & $\begin{array}{l}53 \\
33 \\
29-108\end{array}$ & $\begin{array}{l}189 \\
168 \\
60-475\end{array}$ \\
\hline $\begin{array}{l}\text { Zone D (10 sites): } \\
\text { Means } \\
\text { SD } \\
\text { Ranges }\end{array}$ & $\begin{array}{l}16762 \\
2882 \\
13450-21470\end{array}$ & $\begin{array}{l}423 \\
79 \\
300-530\end{array}$ & $\begin{array}{l}29 \\
13 \\
13-51\end{array}$ & $\begin{array}{l}38 \\
8 \\
24-52\end{array}$ & $\begin{array}{l}36 \\
16 \\
6-65\end{array}$ & $\begin{array}{l}111 \\
45 \\
40-182\end{array}$ \\
\hline $\begin{array}{l}\text { Zone E (7 sites): } \\
\text { Means } \\
\text { SD } \\
\text { Ranges }\end{array}$ & $\begin{array}{l}15804 \\
2294 \\
13160-19500\end{array}$ & $\begin{array}{l}377 \\
63 \\
300-500\end{array}$ & $\begin{array}{l}29 \\
10 \\
13-40\end{array}$ & $\begin{array}{l}37 \\
11 \\
17-52\end{array}$ & $\begin{array}{l}35 \\
4 \\
31-41\end{array}$ & $\begin{array}{l}84 \\
21 \\
53-111\end{array}$ \\
\hline
\end{tabular}

centrations and the SMRs for respiratory cancer in each of the zones, all correlations were positive and those between $\mathrm{Fe}$ and $\mathrm{Cu}$ were statistically significant.

Most of the individual sites with high concentrations of metals were in two areas in the north of the town: close to and west of the active foundry; and in a slightly more distant area east north east of the active foundry, along a line following the canal valley orientated in a north easterly direction from that foundry (fig 2). Intermediate values were generally close to the active foundry, and the lowest values at more distant sites; but some low values were also close to the active foundry on its eastern side. The top ten values for $\mathrm{Fe}$ (>22500 ppm), $\mathrm{Mn}$ (>615 ppm),

Table 3 Correlations and significance values between the concentrations of iron and other metals at individual sites within each of the five zones in Kirkintilloch

\begin{tabular}{|c|c|c|c|}
\hline & $M n$ & $C u$ & $C r$ \\
\hline $\begin{array}{l}\text { Zone A: } \\
\quad \text { (16 sites) }\end{array}$ & $\begin{array}{l}+0.719 \\
\mathrm{p}<0.001\end{array}$ & $\begin{array}{l}+0 \cdot 444 \\
\text { NS }\end{array}$ & $\begin{array}{l}+0.733 \\
\mathrm{p}<0.001\end{array}$ \\
\hline $\begin{array}{l}\text { Zone B: } \\
\quad \text { (12 sites) }\end{array}$ & $\begin{array}{l}+0 \cdot 445 \\
\text { NS }\end{array}$ & $\begin{array}{l}+0 \cdot 196 \\
\text { NS }\end{array}$ & $\begin{array}{l}+0.608 \\
\mathrm{p}<0.036\end{array}$ \\
\hline $\begin{array}{l}\text { Zone C: } \\
\quad \text { (5 sites) }\end{array}$ & $\begin{array}{l}+0 \cdot 700 \\
\text { NS }\end{array}$ & $\begin{array}{l}-0 \cdot 3 \\
\text { NS }\end{array}$ & $\begin{array}{l}+0 \cdot 3 \\
\text { NS }\end{array}$ \\
\hline $\begin{array}{l}\text { Zone D: } \\
\quad \text { (10 sites) }\end{array}$ & $\begin{array}{l}+0.427 \\
\text { NS }\end{array}$ & $\begin{array}{l}+0 \cdot 103 \\
\text { NS }\end{array}$ & $\begin{array}{l}+0 \cdot 2 \\
\text { NS }\end{array}$ \\
\hline $\begin{array}{l}\text { Zone E: } \\
\text { (7 sites) }\end{array}$ & $\begin{array}{l}+0 \cdot 464 \\
\mathrm{NS}\end{array}$ & $\begin{array}{l}-0.821 \\
\mathrm{p}<0.023\end{array}$ & $\begin{array}{l}+0.847 \\
\mathrm{p}<0.016\end{array}$ \\
\hline
\end{tabular}

NS, not significant, $p>0.05$.
$\mathrm{Cu}$ ( $>40 \mathrm{ppm})$, and $\mathrm{Cr}(>59 \mathrm{ppm})$ followed that geographical distribution. The patterns of the top ten values for $\mathrm{Ni}$ and $\mathrm{Pb}$ differed. The $\mathrm{Ni}$ values were usually within an expected range for urban soils, with the striking exception of those at sites 5,6 , and 16 where the values were 352,119 , and $108 \mathrm{mg} / \mathrm{kg}$ respectively; no high values for Ni were found in the east north east area. The top ten values for $\mathrm{Pb}$ were almost completely confined to the two western zones, zones $B$ and C. The test for concordance between the ranks of the metal concentrations of $\mathrm{Fe}, \mathrm{Mn}, \mathrm{Cu}$, and $\mathrm{Cr}$ at all 51 sites was significant $\left(\chi^{2}=114 ; \mathrm{df}=50 ; \mathrm{p}<0.001\right)$.

There were no consistent differences between the concentrations of the metals in the upper and lower halves of the soil core; consequently, a mean concentration was calculated for each site.

\section{Discussion}

Given the urban rural gradient for respiratory cancer in Scotland, the SMRs for Kirkintilloch in the three quinquennia were within the range of values expected for a large town in Scotland. Scotland's rates for respiratory cancer, however, have been among the highest in the world for many years, and had the SMRs for Kirkintilloch been calculated on the basis, for example, of the European rates for respiratory cancer, their values would have been substantially higher.

Air pollution from metallurgical industries has been associated with high values of respiratory cancer 
Smith, Williams, Lloyd $\stackrel{\text { D }}{\mathrm{c}}$

Table 4 Correlations between adjusted SMRs for lung cancer and metal concentrations in each of the zones

\begin{tabular}{lllllll}
\hline$S M R$ & $F e$ & $M n$ & $C u$ & $C r$ & $N i$ & \\
\hline rho & +0.975 & +0.821 & NS & +0.892 & +0.821 & क \\
p Value & 0.005 & 0.042 & NS & NS & NS \\
\hline
\end{tabular}

in adjacent residential communities exposed to steel foundry pollution in Scotland ${ }^{5-8}$ and other countries. ${ }^{2021}$ Within Kirkintilloch the SMRs for the five zones during 1966-77 showed an appreciable gradient, the values declining in accordance with probable diminishing exposure to air pollution from the working foundry - that is, taking into account the factors of distance, prevailing wind directions, and topography. The hypothesis that metallic air pollution might have contributed to the incidence of respiratory cancer is supported by several findings. (1) A clear gradient exists between the high risk zone A (SMR 116) and the low risk zone E (SMR 45). (2) The gradient persisted after standardisation for social class, which was taken as a proxy for smoking habita well established risk factor in the aetiology of respiratory cancer. (3) Female respiratory cancer SMRs, which are unlikely to be influenced by occupational factors and less likely to be attributable to smoking habit, showed a steep gradient; the SMR in zone A reached statistical significance. (4) The respiratory cancer rates of the younger age groups in zones $A$ and $B$ were higher than those in the other three zones. (5) The only enumeration district with a significantly raised SMR was situated east north east of the active foundry, close to the cluster of sites with the highest values of $\mathrm{Fe}, \mathrm{Cr}, \mathrm{Cu}$, and $\mathrm{Mn}$.

The impact of occupation as a major contributor to the gradient of the SMRs was unlikely to have been pronounced, with the possible exception of zone $\mathrm{C}$. Only eight $(7 \%)$ death certificates listed foundry worker as the occupation; five of these, however, were for residents of zone C-which may explain the lack of gradient between zones B and C.

The concentrations of metals in Kirkintilloch were lower than those found in the previous studies in Armadale $^{14}$ and Bathgate, ${ }^{6}$ where the SMRs for respiratory cancer in the polluted zones had also been higher. The concentrations of most metals were high in zones A and B and showed a declining gradient in the zones less exposed to pollution from the foundries. The positive and highly significant correlations of $\mathrm{Fe}$ with both $\mathrm{Mn}$ and $\mathrm{Cr}$ in zone $\mathrm{A}$ was in agreement with the findings of the studies in Armadale and Bathgate; in zone $\mathrm{E}$ the unexpected pairing of the statistically significant positive correlation between $\mathrm{Fe}$ and $\mathrm{Cr}$ and the almost equally significant negative correlation between $\mathrm{Fe}$ and $\mathrm{Cu}$ was probably an example of the statistical artefacts likely to be gener- ated when low concentrations of metals are being $\frac{\overline{\frac{\sigma}{5}}}{\frac{5}{\infty}}$ investigated.

Particles precipitate out of a pollution plume at different rates according to their aerodynamic proper-ties and the characteristics of the prevailing winds. The directions of the flow of a major part of the air $\vec{\omega}$ pollution from the active foundry were illustrated by the positions of the top 20 concentrations for some of ${ }_{\mathbb{D}}$ the metals. On the eastern side of the active foundry, 3 the concentrations followed an "umbrella distribu- + tion"- that is, low values close, and high values fur- $\vec{N}$ ther away at about $1.4 \mathrm{~km}$ (close to the individual district with the significantly high SMR); this pattern $\mathcal{C}$ suggested that the pollution plume contained a higho proportion of small particles which were carried some distance before being precipitated, possibly as a result

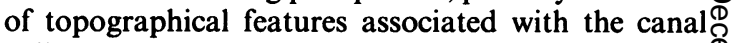
valley. Awareness of the relative ease with which $\frac{\mathbb{S}}{3}$ small particles enter the respiratory tract raises the question about the possible contribution of metallic ${ }^{\text {D }}$ air pollution to the rises in the SMRs for respiratogy $\vec{\oplus}$ disease in these more distant districts north east of the. foundry. If the significantly positive associatiogs between the mean values of the metals $(\mathrm{Fe}$ and $\mathrm{Cu})$ the five zones and the zones' SMRs reflect a causal relation, a dose response effect has been shown.

Both $\mathrm{Pb}$ and $\mathrm{Ni}$ were omitted from the statistical analyses. For $\mathrm{Pb}$, the positions of the sites with high values were generally close to the main roads within the town, indicating the effects of contamination by exhaust emissions from motor vehicles. The concentrations of $\mathrm{Ni}$ within the town also did not follow a regular pattern, exceptionally high values being found $\underset{\Phi}{\triangle}$ at sites 5 and 6 . This observation could not be expla- 3 ined from knowledge of present and recent sources of $\frac{}{3}$ air pollution by metals. When published reports describing the history of the town were examined to determine if an appropriate source had existed during the earlier part of this century, it was found that $a$ 음 nickel refinery had been present at these locations $D$ until the late 1920s. ${ }^{17}$ This finding, of high concentrations of $\mathrm{Ni}$ in soils more than 50 years after the pollution source had been closed, illustrates the usefulness of soil cores in determining the existence of $N$ past pollution by metals.

The absence of a consistent gradient between the 0 values of metals in the upper and lower halves of the soil cores agrees with previous findings ${ }^{14} 15$ where the phenomena of cryoturbation and bioturbation of $\stackrel{\oplus}{?}$ 
$\mathrm{Fe}$

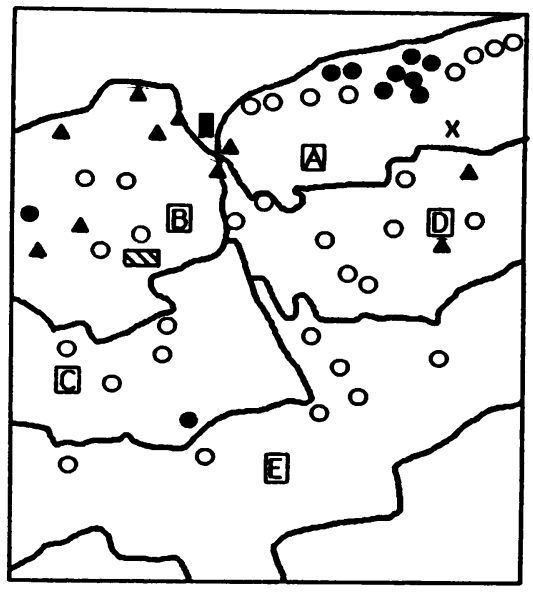

\section{$\mathrm{Cr}$}

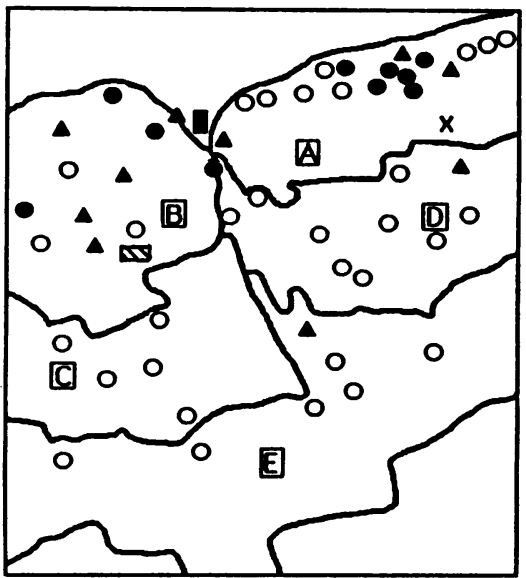

$\mathrm{Pb}$

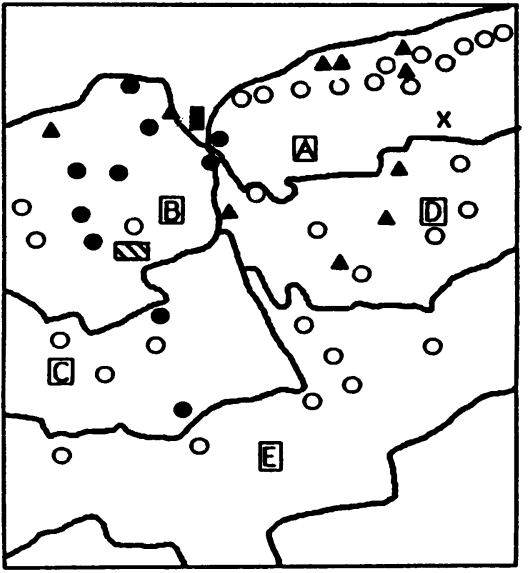

$\mathrm{Mn}$

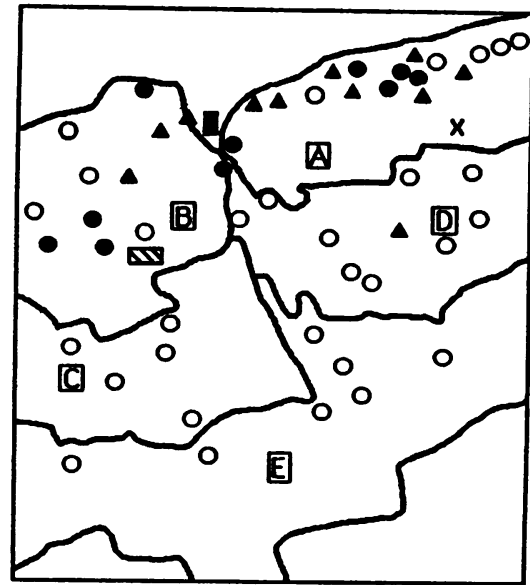

$\mathrm{Cu}$

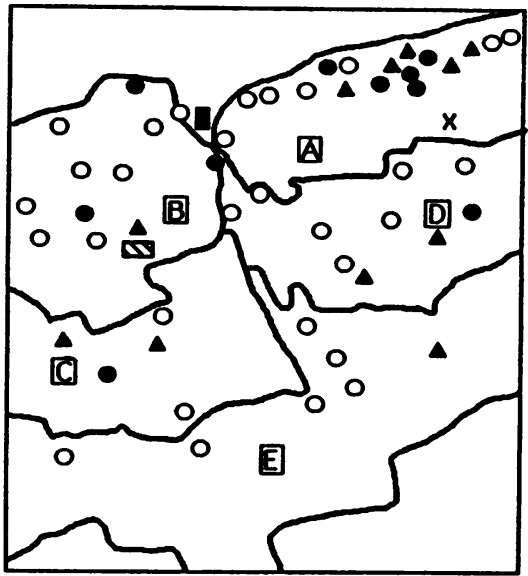

$\mathrm{Ni}$

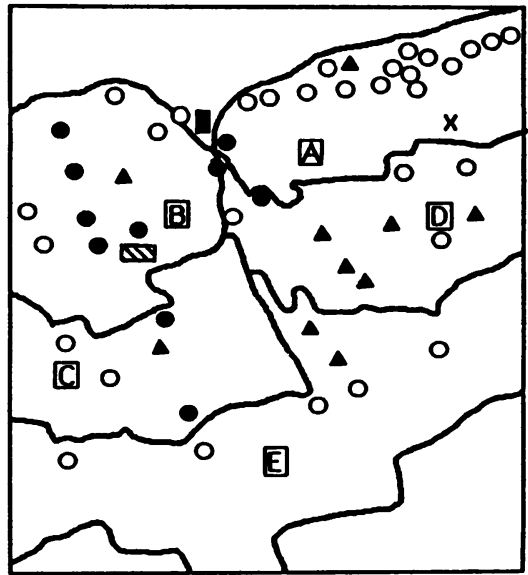

Fig 2 Maps of Kirkintilloch showing the positions of the sites with the values ranked in the top 10 (dark, closed circles) and between 11 and 20 (dark triangles) for iron, manganese, chromium, copper, lead, and nickel (for scale of maps, see fig 1). 
the soil had similar consequences, and reflects the stability of using soil core samples as one method of assessing the patterns of previous atmospheric pollution.

In conclusion, the present study has shown the value of combining small area epidemiological analyses with studies of environmental pollution on a similarly detailed scale: within an industrial town where the overall SMRs for respiratory cancer were unexceptional higher SMRs were found in small residential areas that had been exposed to more pollution from iron foundries than had areas with much lower SMRs. These findings raise again the question about the part played by specific industrial pollutants in the notoriously high Scottish mortality rate for that cancer. For unlike the situation in many other countries, residential areas of Scottish industrial towns are often close to local industries and hence exposed to appreciable amounts of air pollution from them. Nevertheless, it must be remembered that these findings are based on small numbers of deaths and so the epidemiological pattern must be interpreted with caution.

This work forms part of an MSc by GS. We thank Professor C du V Florey for criticism of the manuscript. The chemical analyses were undertaken in the laboratory of the Scottish Occupational and Environmental Health Service, Ninewells Medical School, Dundee.

\section{References}

1 Pedersen E, Hogetveit AC, Andersen A. Cancer of respiratory organs among workers at a nickel refinery in Norway. Int $J$ Cancer 1973;12:32.

2 Office of Population Censuses and Surveys. Occupational mortality 1970-72. London: HMSO, 1978.

3 Radford EP, Milham S, Hirayama T. In: Saffiotti U,
Smith, Williams, Lloyd

Wagoner JK, eds. Occupational carcinogenesis. Ann NY Acaळ Sci 1976;271:228-37, 243-9, 269-72.

4 Morrison SL. Occupational mortality in Scotland. Br J Ind Med 1957;14:130-2

5 Lloyd OLL. Respiratory cancer clustering associated with local ized industrial air pollution. Lancet 1978;i:318-20.

6 Lloyd OLL, Smith G, Lloyd MM, Holland Y, Gailey F. Raisect mortality from lung cancer and high sex ratios of births associo ated with industrial pollution. Br J Ind Med 1985;42:475-80.

7 Lloyd OLL, Williams FLR, Gailey FAY. Is the Armadale epidemic over? Air pollution and mortality from lung cance and other diseases, 1961-82. Br J Ind Med 1985;42:815-23. ه

8 Lloyd OLL, Barclay R, Lloyd MM. Armadale group practice? Lung cancer and other health problems in a Scottish industria 5 town: a review. Ambio 1985;14:322-8.

9 Yule FA, Lloyd OLL. Metal content of an indigenous moss in Armadale, central Scotland. Water Air Soil Pollution 1984;21:261-70.

10 Gailey FAY, Lloyd OLL. Atmospheric metal pollution in a com $\stackrel{\mathbb{D}}{7}$ munity monitored by spherical moss bags. Environ Healt $h^{\beta}$ Perspect 1986;68:187-96.

11 Gailey FAY, Lloyd OLL. The use of Lecanora conizaeoides as 2 monitor of the distribution of atmospheric pollution by metals $N$ Ecology of Disease 1983;2:235-9.

12 Gailey FAY, Smith GH, Rintoul LJ, Lloyd OLL. Metak deposition patterns in central Scotland, as determined byo lichen transplants. Environmental Monitoring and Assessmen? 1985;5:291-309.

13 Gailey FAY, Lloyd OLL. Grass and surface soils as monitors of atmospheric metal pollution in central Scotland. Water Ai尺 Soil Pollution 1985;24:1-18.

14 Smith GH, Lloyd OLL. Patterns of pollution in soils: a com parison of the values obtained by atomic absorption and $\mathrm{x}$-ray fluorescence. Environmental Toxicology and Chemistry 1986;5:117-27.

15 Smith GH, Lloyd OLL, Hubbard F. Soil arsenic in Armadâ

Scotland. Arch Environ Health 1986;41:120-2.
16 Gailey FAY, Lloyd OLL. A wind tunnel study of the flow of pollution in Armadale, central Scotland. Ecology of Diseases 1983;2:419-31

17 Martin D. The story of Kirkintilloch. Strathkelvin Districto Libraries \& Museums, 1980.

18 Diem K, Lentner G, eds. Documenta Geigy scientific tables $\mathbb{Q}$ Macclesfield: Geigy Pharmaceuticals, 1973.

19 Siegel S. Nonparametric statistics for the behavioural sciences. Kogakusha: McGraw-Hill, 1956.

20 Pershagen G. Lung cancer mortality among men living near an arsenic-emitting smelter. Am J Epidemiol 1985;122:684-94.

21 Cecilioni VA. Lung cancer in a steel city. Fluoride 1972;5:172-8 